\title{
MANFAAT AKUPRESUR DALAM MENCEGAH MENOMETRORHARGIA PADA WANITA USIA REPRODUKSI
}

\author{
Annisa Ridlayanti ${ }^{1}$, Imas Masdinarsyah ${ }^{2}$, Anita Yuliani ${ }^{3}$ \\ 1,2,3) Universitas 'Aisyiyah Bandung. \\ annisa_ridlayanti@yahoo.com
}

\begin{abstract}
ABSTRAK
Akupresur merupakan terapi nonfarmakologi yang memiliki manfaat untuk mengurangi rasa nyeri dan perdarahan banyak saat menstruasi. Menometrorhargia merupakan kelainan siklus perdarahan dari dalam rahim yang abnormal dan tidak teratur. Di Indonesia, prevalensi kasus menometrorhargia terjadi sekitar 27\%. Menometrorhargia dapat terjadi pada $20 \%$ wanita mulai usia remaja hingga $40 \%$ pre-menopause. Tujuan dari penelitian ini adalah untuk mengidentifikasi efek dari terapi akupresur dalam mencegah menometrorhargia pada wanita usia reproduksi. Penelitian ini merupakan penelitian eksperimental semu dengan non-equivalent pretest-postest control group design. Sebanyak 15 orang terkumpul sesuai kriteria inklusi. Sampel dibagi menjadi 2 kelompok yaitu 7 kontrol dan 8 treatment. Akupresur diberikan pada kelompok treatment saat mentruasi. Efektivitas terapi dilakukan sebelum dan setelah tindakan dengan memberikan kuesioner. Hasil penelitian menunjukkan dari 8 sampel yang diberikan akupresur efektif menurunkan intensitas nyeri dan perdarahan karena menometrorhargia dibandingkan dengan kelompok kontrol yang hanya 7 sampel akibat menometrorhargia. Hasil signifikansi 95\%, dengan $p$-value $0.02<0,05$. Penelitian ini menunjukkan bahwa terapi akupresur efektif dalam menurunkan nyeri dan perdarahaan akibat menometrorhargia pada wanita usia reproduksi di lingkungan Universitas 'Aisyiyah Bandung. Terapi akupresur dapat dijadikan salah satu alternatif dalam mencegah menometrorhargia.
\end{abstract}

Kata kunci : akupresur, menometrorarghia, usia reproduksi

\section{Abstract}

Acupressure is a non-pharmacological therapy that has benefits to reduce pain and to bleed a lot during menstruation. Menometrorhargia is abnormal and irregular uterus bleeding. In Indonesia, prevalence menometrorhargia is about 27\%. Menometrorhargia can occur in $20 \%$ of women start at early adolescence $40 \%$ pre-menopause toward the end of menstruation. The purpose of this study was to identify the therapeutic effects of acupressure to prevent menometrorrhagia of women of reproductive age. The research method is quasi-experimental with non-equivalent pretest-posttest control group designas many as 15 samples collected by criteria inclusion. Samples divide into two groups, seven samples in control groups and eight samples in treatment groups. Acupressure gives then the samples get menstruation-the effectiveness of therapy done before and after menstruation by giving questionnaire. This study shows that eight samples in treatment feel effective in reducing the intensity of the pain and bleeding because menometrorrhagia if compared to the control. The significance is $95 \%$ with p-value 0.02 $<0,05$. This research shows accupressure therapy is effective in reducing the pain and heavy bleeding due to menometrorgargia in women reproductive age at around 'Aisyiyah Bandung University. This non-pharmacological therapy can be one of the alternatives in reducing menometrorrhagia.

Keywords : acupressure, menometrorarghia, reproductive age 


\section{PENDAHULUAN}

Prevalensi menometrorhargia pada wanita usia reproduksi dapat dikatakan cukup tinggi berkisar 20-40\%. Di Indonesia sendiri prevalensi tersebut mencapai 27\% (Maryam et al., 2016).

Menometrorhargia merupakan masalah ginekologis yang sering dikeluhkan oleh sebagian besar wanita usia reproduksi. Menometrorhargia merupakan perdarahan uterus abnormal tanpa penyebab organik atau gangguan organ saat menstruasi. Menometrorhargia terjadi karena ketidakseimbangan hormon yang mengatur siklus menstruasi dan kondisi medis lainnya.

Perdarahan uterus abnormal dapat dipicu karena obesitas, pekerjaan berat, dan stress. Menometrorhargia dapat diiringi dengan gelaja nyeri haid yang dikarenakan kondisi lapisan endometrium berada pada fase sekresi sehingga mulai memproduksi prostaglandine (PGF2a) berlebih yang berakibat pada hipertonik dan vasokontriksi myometrium. Kondisi ini mengakibatkan iskemia, disintegrasi dinding endometrium, perdarahan, dan nyeri (Iorno et al., 2008).

Beberapa upaya dalam mengurangi gejala-gejala yang dirasakan karena kondisi menometrorhargia yakni medical therapy dan non medical therapy. Medical therapy atau terapi medis yang umum digunakan berupa obat hormonal seperti pil KB/progestine, anti nyeri dan anti peradangan seperti asam mefenamat, ibuprofen dan kalsium antagonis seperti verapamil dan nifedipin yang dapat menurunkan aktivitas dan kontraktilitas uterus (Petraglia et al., 2017).

Selain itu terapi alami atau natural (non medical therapy) yang aman dilakukan yakni dengan exercise/ latihan, mandi air hangat/ sauna, memakai buli-buli panas, meditasi, serta dapat juga dengan pemberian suplemen, pengobatan herbal, terapi horizon, terapi bedah,
Transcutaneus Electrical Nerve Stimulation (TRANS) akupuntur, dan akupresur (Petraglia et al., 2017).

Akupresur merupakan salah satu pengobatan komplementer. Pengobatan ini berasal dari Cina dan telah dikenal sejak ribuan tahun lalu. Teknik yang digunakan pada akupresur adalah dengan cara memberikan tekanan atau pemijatan sebagai stimulasi pada titik-titik tertentu dalam tubuh. Awalnya terapi akupresur merupakan pengembangan dari teknik akupuntur yang menggunakan media jarum, sedangkan teknik akupresur menggunakan jari tangan atau benda tumpul sebagai media. Tujuan akupresur untuk merangsang kemampuan tubuh secara alami. Rangsangan secara alami ini digunakan untuk mengembalikan keseimbangan energi positif tubuh (Gharloghi et al., 2012); (Dong, 2018.); (Maryam et al., 2016).

Sebuah penelitian membuktikan bahwa intensitas dismenorea dapat menurun setelah diberikan terapi akupresur pada remaja putri (Ignacio \& Orso, 2016). Ditambahkan pula oleh Ansaripour (2016) terapi akupresur dapat menurunkan intensitas nyeri akibat dismenorea. (Ansaripour et al., 2016).

\section{METODOLOGI}

Rancangan ini menggunakan eksperimental semu dengan non equivalent pre test and post test designs. Penilaian dilakukan dengan membandingkan hasil yang didapat sebelum dan sesudah diberi terapi akupresur pada sampel penelitian. Teknik sampling dilakukan dengan cara purposive sampling. Visual Analog Scale (VAS) dilakukan untuk mengukur intensitas nyeri. Pada pembacaan skala Numerik VAS berbentuk grafik sepanjang $10 \mathrm{~cm}$, ujung sebelah kiri menggambarkan kondisi tidak dirasakan nyeri dan ujung sebelah kanan mengambarkan nyeri sangat berat. Untuk data kualitatif pengukuran nyeri menggunakan 
data kualitatif.

Pada kelompok perlakuan peneliti melakukan terapi akupresur pada titik PC6 dan LI4 sebanyak tiga kali dalam sehari, lamanya 30 menit dan jeda 10 menit setiap perlakuan. Sedangkan kelompok kontrol diberikan perlakuan tetapi berbeda dengan kelompok kontrol perlakuan yang diberikan adalah terapi sentuhan ringan pada titik yang sama tanpa penekanan. Pengukuran skala numerik VAS dilakukan sebelum dan sesudah perlakuan pada kedua titik selama satu hari yang sama. Tempat Penelitian di Lingkungan STIKes 'Aisyiyah Bandung. Waktu penelitian ini dimulai bulan Januari sampai dengan Maret 2020.

Populasi pada penelitian ini adalah seluruh mahasiswi di Lingkungan Universitas 'Aisyiyah Bandung dengan sampel penelitiannya adalah mahasiswa yang mengalami dismenorea. Purposive sampling digunakan sebagai teknik sampling dan didapat kelompok kontrol (17 orang) dan kelompok treatment (16 orang) yang memenuhi kriteria inklusi. Data primer dikumpulkan langsung dari objek penelitian antara kelompok kontrol dan intervensi dengan menggunakan alat ukur. Setelah itu, peneliti mengidentifikasi skor intensitas nyeri yang telah dilakukan dengan VAS dan kuesioner. Peneliti melakukan teknik akupressure pada kelompok intervensi seperti yang telah dijelaskan sebelumnya.

\section{HASIL}

Gambaran sosiodemografik antara kelompok kontrol dan intervensi disajikan pada tablel 1 .

Pengukuran menometrorarghia atau perdarahan uterus abnormal dilakukan dengan skrining dan pemeriksaan fisik serta penunjang apabila diperlukan. Pasien dapat mengalami gejala perdarahan banyak dan disertai nyeri saat menstruasi. Selain itu. termasuk gejala gastrointestinal (seperti nausea, vomitting, dan diarhea), gejala stress dan ketidaknyamanan, nyeri payudara, dan nyeri pinggang/ panggul. Pengukuran lain terkait umur saat menarche, durasi menstruasi, banyaknya jumlah darah, dan pola siklus menstruasi juga dilaksanakan dan hasil analisa statistik didapatkan tidak ada antara kelompok kontrol dan intervensi terhadap keseluruhan pengukuran tersebut secara signifikan.

Tabel 1. Karakteristik Sosiodemografik Sampel Penelitian

\begin{tabular}{|c|c|c|c|c|}
\hline \multirow{2}{*}{ Variabel } & \multicolumn{2}{|c|}{$\begin{array}{c}\text { Sample Penelitian } \\
(\mathrm{n}=15=100 \%)\end{array}$} & \multirow{2}{*}{$x^{2}$} & \multirow{2}{*}{$\mathbf{p}$} \\
\hline & $\begin{array}{c}\text { Kontrol } \\
(n=7=46,7 \%)\end{array}$ & $\begin{array}{c}\text { Intervensi } \\
(n=8=53,3 \%)\end{array}$ & & \\
\hline \multicolumn{5}{|l|}{ Age (years) } \\
\hline$<20$ & 0 & 0 & \multirow{3}{*}{3,44} & \multirow{3}{*}{$\begin{array}{c}0,16 \\
\text { (not Signifikan) }\end{array}$} \\
\hline $20-35$ & $7(46,7 \%)$ & $6(40,0 \%)$ & & \\
\hline$>35$ & 0 & $2(13,3 \%)$ & & \\
\hline \multicolumn{5}{|l|}{ Status sosioekonomi } \\
\hline Kurang & 0 & 0 & \multirow{2}{*}{3,53} & 0,19 \\
\hline Cukup & $7(46,7 \%)$ & $8(53,3 \%)$ & & (not signifikan) \\
\hline
\end{tabular}




\begin{tabular}{|c|c|c|c|c|}
\hline \multirow{2}{*}{ Variabel } & \multicolumn{2}{|c|}{$\begin{array}{l}\text { Sample Penelitian } \\
\quad(\mathrm{n}=15=100 \%)\end{array}$} & \multirow{2}{*}{$x^{2}$} & \multirow{2}{*}{$\mathbf{p}$} \\
\hline & $\begin{array}{c}\text { Kontrol } \\
(n=7=46,7 \%)\end{array}$ & $\begin{array}{c}\text { Intervensi } \\
(n=8=53,3 \%)\end{array}$ & & \\
\hline \multicolumn{5}{|l|}{$\mathrm{BMI}\left(\mathrm{kg} / \mathrm{m}^{2}\right)$} \\
\hline$<25$ & 0 & 0 & \multirow{3}{*}{1,57} & \multirow{3}{*}{$\begin{array}{c}0,67 \\
\text { (not signifikan) }\end{array}$} \\
\hline $25-35$ & $5(33,3 \%)$ & $7(46,7 \%)$ & & \\
\hline$>35$ & $2(13,2 \%)$ & $1(6,7 \%)$ & & \\
\hline
\end{tabular}

Hasil penelitian pada tabel 1 menunjukkan bahwa pada kelompok kontrol sebanyak 46,7\% sampel berusia 20-35 tahun. Adapun kelompok intervensi $40 \%$ berada di usia reproduksi dan $13,3 \%$ berusia $>35$ tahun namun masih mengalami menstruasi. Pada pengukuran Body Mass Index, menunjukkan sebagian besar sampel baik kelompok kontrol maupun intervensi menunjukkan tidak mengalami obesitas.

Hasil pengukuran efektivitas akupresur pada kasus menometrorhargia dilihat dari prates dan pascates yang dilakukan. Variabel yang diukur adalah jumlah perdarahan, nyeri haid, kecemasan, dan gangguan gastrointestinal berupa mual dan muntah Hasil nya dapat dilihat pada grafik 1 dan 2 .

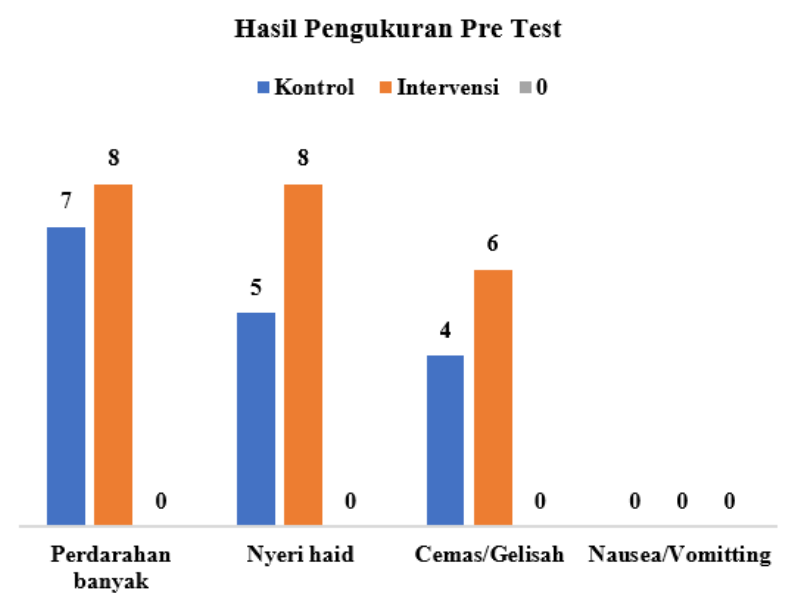

\section{Grafik.1. Hasil pengukuran pre-test kelompok kontrol dan intervensi.}

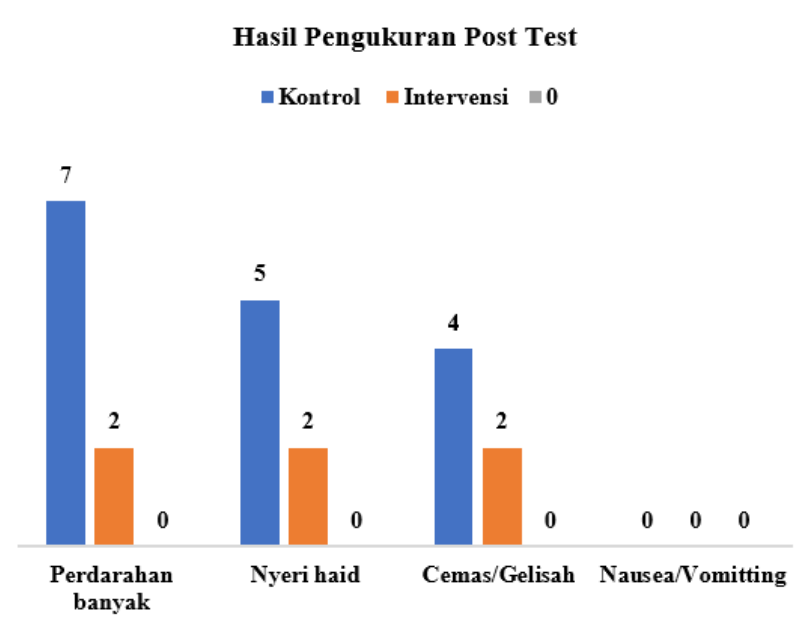

\section{Grafik.2. Hasil pengukuran Post-test kelompok kontrol dan intervensi.}

\section{PEMBAHASAN}

Pada grafik.1 menunjukkan jumlah sampel yang mengalami perdarahan banyak, nyeri haid, dan cemas antara kedua kelompok lebih banyak dialami oleh kelompok intervensi. Setelah dilakukan intervensi akupresur pada kelompok intervensi, Hasil menunjukkan signifikan pada kelompok intervensi mengalami penurunan gejala-gejala tersebut. Sebanyak 6 orang berkurang jumlah perdarahan dan nyeri haid yang dirasakan. Ditambah 4 orang merasakan lebih rileks setelah dilakukan terapi akupresur. Uji analisis dilakukan antara sebelum dan sesudah tindakan. Hasil Uji Mann Whitney menunjukkan $p$-value $0.02<0.05$ yang berarti ada perbedaan antara hasil sebelum dan sesudah 
tindakan akupresur. Dengan demikian dapat dianalisis bahwa ada pengaruh pemberian terapi akupresur terhadap wanita usia subur yang mengalami menometrorarghia.

Studi ini sejalan dengan temuan Kashefi (2010) dan Christina et al (2018) yang membuktikan efektivitas akupresur pada titik SP6 secara signifikan dapat menurunkan tingkat kesakitan saat menstruasi. Selain itu penelitiannya juga menunjukkan bahwa akupresur merupakan alternatif terapi yang efektif, mudah, dan murah untuk menurunkan nyeri saat menstruasi (Kashefi et al., 2010; Christina et al., 2016). Ditambahkan pula oleh Jiang (2016) bahwa akupresur dapat menurunkan tingkat kesakitan akibat dismenorea antara kelompok kontrol dan intervensi. Intervensi akupresur pada titik SP6 efektif menghilangkan nyeri dan stres menstruasi akibat dismenorea (Jiang et al., 2013). Selain itu, akupresur pada titik SP6 dan SP8 dapat menurunkan volume perdarahan dan nyeri saat menstruasi selama 2 jam terapi (Gharloghi et al., 2012)50 females aged 18-30 years old who met the study criteria and were under the care of Sarpolezahab Health Center were selected. Subjects were randomly assigned to one of two groups and evaluated during three menstrual cycles. We evaluated pain severity using the McGill pain scale and associated systemic symptoms using a verbal multidimensional scoring system. Data acquired from 42 cases were analyzed using SPSS software, with a $\mathrm{P}$ value of $<0.05$ considered significant. Results: The findings of our study indicate that the severity of dysmenorrhea pain diminishes significantly for up to 2 hours following treatment with acupressure at the SP6 and SP8 points $(\mathrm{P}<0.001$.

Dalam studi ini juga menemukan bahwa rata-rata skala penurunan skala nyeri pada kelompok intervensi sebelum dan setelah tindakan akupresur adalah 6 orang (75\%). Akupresur dapat menurunkan nyeri dengan cara meningkatkan hormon relaksasi yakni hormon endorfin tubuh secara alami. Selain itu, teknik akupresur juga dapat memblok reseptor nyeri ke otak (Wang et al., 2013)physical activity and functioning, and quality of life. Unfortunately, stress increases the sensitivity and severity of pain, activating sympathetic responses while inhibiting parasympathetic responses. Objective. This study used objective, physiological measurements to evaluate the effects of auricular acupressure on menstrual pain and menstrual distress in young college students with primary dysmenorrhea across two menstrual cycles. The aim was to determine if significant differences could be detected between the intervention and followup phases after controlling life stress. Design. A one-group experimental research design was used, and repeated measurements and followups were done. Thirty-two women completed questionnaires and physiological parameters were measured. Results. Significant differences between the intervention and follow-up phases were found for high frequency (HF. Penekanan pada titik akupresur dapat menstimulasi jaringan syaraf untuk melepaskan hormon endorfin sesuai kebutuhan tubuh (Qorbanalipour et al., 2018) complementary or surgical treatments. The aim of the present randomized clinical trial (RCT. Peningkatan hormon endorfin dalam darah dan opioid peptide endogenous di susunan saraf pusat secara alami dapat menurunkan intensitas nyeri yang dirasakan tubuh. Selain itu akupresur juga dapat membuka penyumbatan pada pembuluh darah vena, merangsang simpul saraf dan pusat saraf serta fungsi-fungsi kelenjar dalam tubuh (Blödt et al., 2018); (Christina et al., 2016), Studi ini sejalan dengan hasil penelitian Othman et al (2020) yang menyebutkan bahwa akupresur SP6 sangat efektif dalam menurunkan nyeri serta merupakan metode alami, sederhana, sesuai kebutuhan, murah, efisien untuk menurunkan nyeri (Azzam et al., 2018)dopamine D1 receptor 
gene (DRD1. Ditambahkan pula pada beberapa penelitian lain yang membandingkan akupresur selama 20 menit dengan sentuhan ringan pada kelompok penelitiannya, hasilnya menunjukan bahwa terdapat perbedaan signifikan pada skala VAS antara kelompok kontrol dan intervensi serta tidak ada efek samping yang didapat setelah terapi diberikan (Ansaripour et al., 2016; Kurniyawan., 2016).

\section{SIMPULAN DAN SARAN}

Penelitian ini menunjukkan bahwa terapi akupresur efektif dalam menurunkan kejadian menometrorarghia pada perempuan usia reproduksi di lingkungan Universitas 'Aisyiyah Bandung. Terapi non farmakologis ini dapat dijadikan salah satu alternatif dalam mengobati menometrorarghia. Terapi akupresur merupakan salah satu warisan holistic care yang dapat diterapkan pada masyarakat.

\section{DAFTAR PUSTAKA}

Ansaripour, L., Morshed Behbahani, B., Akbarzadeh, M., \& Zare, N. (2016). Comparison of the influence of acupressure and self-care behavior education on the severity of primary dysmenorrhea based on visual analogue scale among students. International Journal of Medical Research \& Health Sciences, 5, 200-207. www.ijmrhs.com

Azzam, A. A. A., Behgat, D. M. R., Shahin, R. M. H., \& Nasralla, R. M. A. (2018). Association study between polymorphisms of dopamine transporter gene (SLC6A3), dopamine D1 receptor gene (DRD1), and autism A. Journal of Medicine in Scientific Research, 1(1), 26-29. https://doi.org/10.4103/JMISR. JMISR

Blödt, S., Pach, D., Eisenhart-Rothe, S. von, Lotz, F., Roll, S., Icke, K., \& Witt, C. M.
(2018). Effectiveness of app-based selfacupressure for women with menstrual pain compared to usual care: a randomized pragmatic trial. American Journal of Obstetrics and Gynecology, 218(2), 227. e1-227.e9. https://doi.org/10.1016/j. ajog.2017.11.570

Christina, E., Sahu, G., Saha, P., Sharma, P., Bano, S., Gaur, B. S., \& Malviya*, R. (2016). Effectiveness of acupressure therapy on menstrual pain perception among adolescent girls with primary dysmenorrhea. International Journal of Bioassays, 5(10), 4939. https://doi. org/10.21746/ijbio.2016.10.005

Dong, H. (n.d.). Acupuncture for the management of dysmenorrhea dysmenorrhea. http:// www.gfmer.ch/Presentations_En/Pdf/ Acup_Dysmenorrhea.pdf

Gharloghi, S., Torkzahrani, S., Akbarzadeh, A. R., \& Heshmat, R. (2012). The effects of acupressure on severity of primary dysmenorrhea. Patient Preference and Adherence, 6, 137-142. https://doi. org/10.2147/PPA.S27127

Ignacio, J., \& Orso, D. (2016). No 主観的健康 感を中心とした在宅高齢者における 健康関連指標に関する共分散構造分 析Title. April.

Iorno, V., Burani, R., Bianchini, B., Minelli, E., Martinelli, F., \& Ciatto, S. (2008). Acupuncture treatment of dysmenorrhea resistant to conventional medical treatment. Evidence-Based Complementary and Alternative Medicine, 5(2), 227-230. https://doi. org/10.1093/ecam/nem020

Jiang, H. R., Ni, S., Li, J. L., Liu, M. M., Li, J., Cui, X. J., \& Zhang, B. M. (2013). Systematic review of randomized clinical trials of acupressure therapy for primary dysmenorrhea. 
Evidence-Based Complementary and Alternative Medicine, 2013. https://doi. org/10.1155/2013/169692

Kashefi, F., Ziyadlou, S., Khajehei, M., Ashraf, A. R., Reza Fadaee, A., \& Jafari, P. (2010). Effect of acupressure at the Sanyinjiao point on primary dysmenorrhea: A randomized controlled trial. Complementary Therapies in Clinical Practice, 16(4), 198-202. https://doi. org/10.1016/j.ctcp.2010.04.003

Kurniyawan, H. E. (2016). Terapi Komplementer Alternatif Akupresur Dalam Menurunkan Tingkat Nyeri. NurseLine Journal, 1(2), 246-256. https://media.neliti.com/media/ publications/197137-ID-acupressure-ascomplementary-and-alterna.pdf

Maryam, Ritonga, M. A., \& Istriati. (2016). Relationship between Menstrual Profile and Psychological Stress with Dysmenorrhea. Althea Medical Journal, 3(3), 382-387. https://doi.org/10.15850/ amj.v3n3.884
Petraglia, F., Bernardi, M., Lazzeri, L., Perelli, F., \& Reis, F. M. (2017). Dysmenorrhea and related disorders. F1000Research, 6(0), 1-7. https://doi.org/10.12688/ f1000research.11682.1

Qorbanalipour, K., Ghaderi, F., \& Jafarabadi, M. A. (2018). Comparison of the effects of acupressure and electroacupuncture in primary dysmenorrhea: A randomized controlled trial. International Journal of Women's Health and Reproduction Sciences, 6(4), 471-476. https://doi. org/10.15296/ijwhr.2018.78

Wang, Y. J., Hsu, C. C., Yeh, M. L., \& Lin, J. G. (2013). Auricular acupressure to improve menstrual pain and menstrual distress and heart rate variability for primary dysmenorrhea in youth with stress. Evidence-Based Complementary and Alternative Medicine, 2013. https://doi. org/10.1155/2013/138537 
